\title{
Binding of environmental carcinogens to asbestos and mineral fibres
}

\author{
G HARVEY, M PAGÉ, AND L DUMAS \\ From Department of Biochemistry, Faculty of Medicine, Université Laval, Québec, Canada G1 K 7P4
}

ABSTRACT A rapid method has been developed for measuring the binding capacity of asbestos and other mineral fibres for environmental carcinogens. Benzo $(\alpha)$ pyrene $(\mathrm{B}(\alpha) \mathrm{P})$, nitrosonornicotine (NNN), and N-acetyl-2-aminofluorene (NAAF) were assayed in the presence of Canadian grade 4T30 chrysotile, chrysotile A, amosite, crocidolite, glass microfibres, glasswool, attapulgite, and titanium dioxide. Chrysotile binds significantly more carcinogens than the other mineral fibres. This binding assay is reproducible with coefficients of variation of less than $8 \%$ and $6 \%$ respectively for inter and intra assay. The influence of $\mathrm{pH}$ was also studied, and there is good correlation between the carcinogen binding and the charge of the tested mineral fibres. The in vitro cytotoxicity on macrophage like cell line $P 388 D_{1}$ and the haemolytic activity of various mineral fibres were also measured; a good correlation was found between the binding capacity

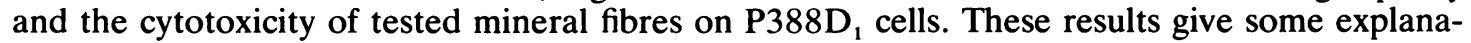
tions for the reported synergism between exposure to asbestos and the smoking habits of workers.

The potentially harmful effects of all types of respirable mineral fibres are at present one of the most important fields of interest in industrial hygiene. Epidemiological data ${ }^{2}$ suggest that most lung cancers in asbestos workers result from the synergistic effect between asbestos exposure and the smoking habit. In addition to being a physical carcinogen, ${ }^{3}$ asbestos may also increase the effect of other potent carcinogens. ${ }^{45}$ For the induction of lung cancer, the inhaled carcinogen must be retained by the lungs, ${ }^{\circ}$ and this induction may be facilitated by absorption on to asbestos, thus retarding its pulmonary clearance and causing an enhancement of the total exposure level to the carcinogen. ${ }^{7}$ Many investigators $^{89}$ have shown the absorptive capacity of asbestos for carcinogens and various organic compounds and ions.

Owing to its binding capacity for carcinogens present in the environment or in tobacco smoke, asbestos may be a cancer promoter. It is therefore necessary to identify which mineral fibres interact with carcinogens to induce neoplasia. The present data describe the binding capacity of mineral fibres for three carcinogens and the correlation with some in vitro biological assays.

Received 16 May 1983

Accepted 13 June 1983

\section{Materials and methods}

All experiments were carried out with Rhodesian chrysotile A, crocidolite, and amosite obtained from International Union Against Cancer (UICC), Canadian grade 4T30 chrysotile and attapulgite (fibrous clay) obtained from the Research Institute for Asbestos Development (IRDA), and glass fibre (microfibre from GF/C microfilter), glasswool, and titanium dioxide (a synthetic amorphous sample) obtained from Fisher Scientific. Macrophage-like cell line $\mathrm{P} 388 \mathrm{D}_{1}{ }^{10}$ was obtained from American Type Culture Collection (Rockville, Md, USA). $\operatorname{Benzo}(\alpha)$ pyrene $\left[{ }^{3} \mathrm{H}\right](28 \mathrm{Ci} / \mathrm{mmol})$, nitrosonornicotine, $\mathrm{N}^{\prime}$-[pyrrolidine- $2-{ }^{14} \mathrm{C}$ ] $(18.4 \mathrm{mCi} / \mathrm{mmol})$ and $\mathrm{N}$-acetyl-2-aminofluorene $\left[9-{ }^{14} \mathrm{C}\right] \quad(46 \cdot 16$ $\mathrm{mCi} / \mathrm{mmol})$ were purchased from New England Nuclear (Montréal, Canada).

\section{BINDING ASSAY}

One millilitre of a suspension of each test material $(2 \mathrm{mg} / \mathrm{ml})$ was mixed on vortex with $400 \mu \mathrm{l}$ of labelled carcinogen $(1 \mu \mathrm{Ci}$ for $\mathrm{B}(\alpha) \mathrm{P}$ and $0 \cdot 1 \mu \mathrm{Ci}$ for NNN and NAAF), washed five times, and counted. The buffer used in this experiment was Dulbecco's phosphate buffer saline ${ }^{11}$ to which was added $10 \%$ ethanol and $0.25 \%(\mathrm{v} / \mathrm{v})$ benzene for the $\mathrm{B}(\alpha) \mathrm{P}$ assay and 5\% ethanol for NNN and NAAF assays. 
Table 1 Specific surface areas of mineral fibres

\begin{tabular}{lc}
\hline & $\begin{array}{l}\text { Surface areas } \\
\mathrm{m}^{2} / \mathrm{g}\end{array}$ \\
\hline Glasswool & $0 \cdot 1963$ \\
Glass microfibres & $2 \cdot 864$ \\
Amosite & $6 \cdot 000$ \\
Titanium dioxide & $9 \cdot 088$ \\
Crocidolite & $10 \cdot 24$ \\
4T30 Canadian chrysotile & $19 \cdot 39$ \\
UICC chrysotile A & $19 \cdot 61$ \\
Attapulgite & $123 \cdot 0$ \\
\hline
\end{tabular}

This has been determined by solubility measurements.

The binding assay was performed in polypropylene centrifuge tubes obtained from Simport (Beloeil, Canada), and centrifugation was carried out with a Beckman Microcentrifuge B. Radioactivity was counted with Beta Rack counter (LKB, Wallac Oy, Finland).

The results are expressed in percentage of binding and each test was performed in triplicate.

EFFECT OF MINERAL FIBRES ON WATER ACIDITY Speil and Leineweber have shown that the surface charge of mineral fibres is $\mathrm{pH}$ dependent. ${ }^{12}$ It has also been shown that the binding of particular ligands on various surfaces is related to temperature, time, the ionisation status, and the available surface area. ${ }^{13}$ To compare the surface charges of various mineral fibres, the $\mathrm{pH}$ change, caused by a constant amount of fibres, was measured for 15 minutes. Three hundred milligrams of fibres were added to 150 millilitres of deionised water at room temperature. Fibres were kept in suspension with a magnetic stirrer and the $\mathrm{pH}$ was measured at five minute intervals with a Corning Digital $110 \mathrm{pH}$ meter using a polymer body combination electrode.

\section{HAEMOLYSIS}

One millilitre of a $2 \%$ suspension of sheep erythrocytes in $0.02 \mathrm{M}$ Tris $\mathrm{HCl}$ buffer (with $0.12 \mathrm{M} \mathrm{NaCl}$ ) at $\mathrm{pH} 7.3$ was added to $30 \mathrm{mg}$ of each fibres sample in $3 \mathrm{ml}$ of the same buffer. After a 50 minute period of incubation at $37^{\circ} \mathrm{C}$, each test tube was centrifuged and the optical density (OD) of the supernatant was measured at $541 \mathrm{~nm}$.

The percentage of haemolysis was calculated as follows:

OD 541 (test) - OD 541 (O\% haemolysis) $* \times 100$

OD 541 (100\% haemolysis)**

* $0 \%$ of haemolysis: $\mathrm{RBC}$ in Tris- $\mathrm{HCl}$ (without fibre).

** $100 \%$ of haemolysis: RBC in deionised water.
CYTOTOXICITY

Three hundred thousand macrophage-like cells P388D $_{1}$ were mixed with $1000 \mu \mathrm{g}$ of the different fibres in test tubes containing $1 \mathrm{ml}$ of RPMI 1640 medium without Fetal Bovine Serum. After four hours of incubation at $37^{\circ} \mathrm{C}$, the acute cytotoxicity was measured by the Trypan blue dye exclusion method. ${ }^{14}$ The results are expressed in relative toxicity and each test was performed in triplicate.

\section{SURFACE AREA MEASUREMENTS OF MINERAL FIBRES (TABLE 1)}

The specific surface of each mineral fibre tested was evaluated with BET apparatus ${ }^{15}$ (Micrometrics 2100) using krypton for glass microfibres and glasswool and nitrogen for all other fibres.

\section{Results}

\section{BINDING ASSAY}

Figure 1 illustrates the binding capacity of different mineral fibres for benzo $(\alpha)$ pyrene, nitrosonornicotine, and $\mathrm{N}$-acetyl-2-aminofluorene. Results are expressed in percentage of binding. Chrysotile binds significantly more carcinogens than other mineral fibres $(p<0.005)$ except for attapulgite, a fibrous clay used as a substitute to asbestos which binds as much carcinogen as chrysotile.

EFFECT OF MINERAL FIBRES ON WATER ACIDITY When mineral fibres were added to deionised water, a $\mathrm{pH}$ rise was recorded (fig 2); this change in $\mathrm{pH}$ was especially important for chrysotile and attapulgite.

HAEMOLYSIS AND CYTOTOXICITY (TABLE 2)

We found that titanium dioxide, glasswool, crocidolite, and amosite samples caused negligible haemolysis. This is in agreement with the results reported by Daniel and Le Bouffant. ${ }^{16}$ Toxicity studies with the same fibres showed that chrysotile and attapulgite are the most toxic fibres. Titanium dioxide and crocidolite are also toxic. This is in contrast with the results obtained with the haemolysis assay or the ones reported by Wright et $\cdot a l .{ }^{17}$ The latter, however, measured the toxicity after 24 and 48 hours whereas our assay measures the acute effects on the cell membranes which influence Trypan blue uptake.

\section{CORRELATION}

We found a good correlation between the binding capacity and all other tests performed with mineral fibres (table 3). Furthermore, there is a strong correlation between the carcinogen binding capacity, the charge of the tested mineral fibres, the haemolytic activity, and the toxicity. These results are not in 
agreement with the results of Wade et al ${ }^{18}$ and Daniel and Le Bouffant ${ }^{16}$ where doubts have been raised on the value of haemolysis as a predictive assay system. We found a good correlation between the surface area of mineral fibres, the binding of NNN and NAAF, and the toxicity, whereas the correlation between the surface area and the other tests was not significant.

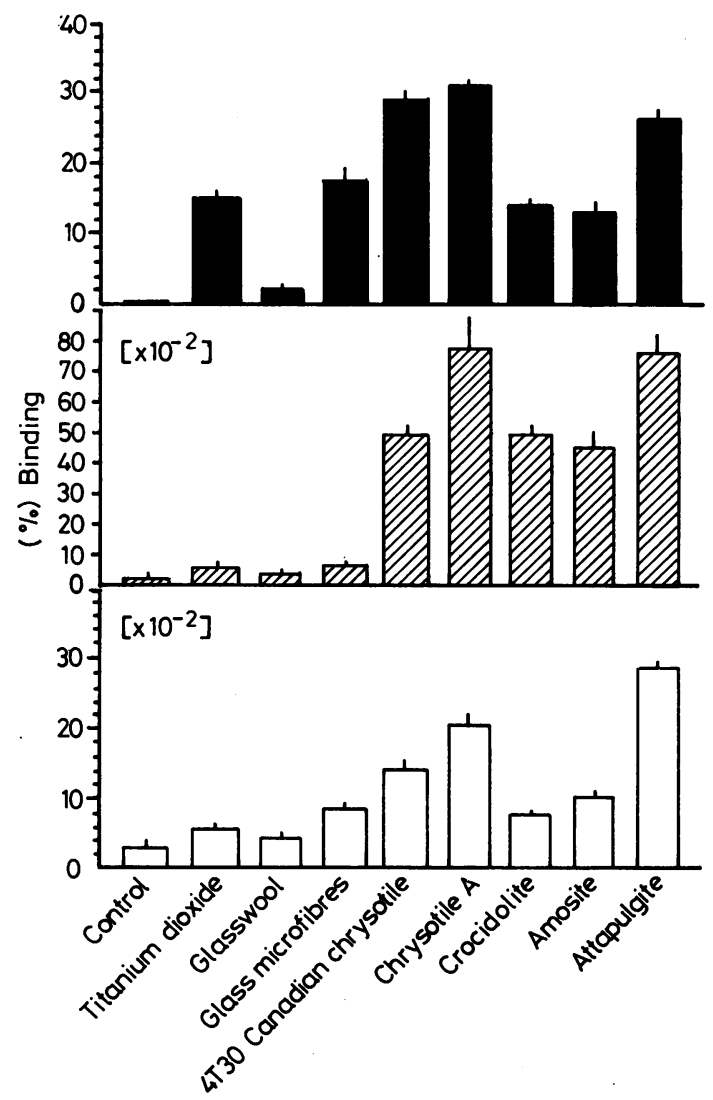

Fig 1 Binding capacity of tested mineral fibres for benzo $(\alpha)$ pyrene $(\square)$, nitrosonornicotine $(\square)$ and $N$-acetyl-2-aminofuorene ( $\square$ ).
Table 2 Haemolytic activity and toxicity of mineral fibres

\begin{tabular}{lll}
\hline & $\begin{array}{l}\text { Relative } \\
\text { haemolysis }\end{array}$ & $\begin{array}{l}\text { Relative } \\
\text { toxicity }\end{array}$ \\
\hline Titanium dioxide & 1.00 & 1.00 \\
Glasswool & 1.00 & 1.00 \\
Glass microfibres & 3.56 & 1.00 \\
Amosite & 1.26 & 1.00 \\
Crocidolite & 1.05 & 1.50 \\
Attapulgite & 3.72 & 4.26 \\
UICC chrysotile A & 5.00 & 4.63 \\
4T30 Canadian chrysotile & 2.44 & 5.00 \\
\hline
\end{tabular}

* All results are expressed in relative values of toxicity or haemolysis ranging from 1.00 to $5 \cdot 00$.

\section{Discussion}

An increasing number of reports support the hypothesis that asbestos may not be a true carcinogen but a promoter. Miller $e \boldsymbol{~ a l}^{19}$ and Shabad $e t$ $a l^{20}$ could not induce tracheal carcinoma by asbestos instillation alone whereas polycyclic aromatic hydrocarbons could induce bronchoalveolar carcinoma. by themselves. The addition of both polycyclic aromatic hydrocarbons and asbestos increased the incidence of carcinoma. Mossman et al also suggested the promoter like action of asbestos fibres. ${ }^{21}$ The presence of inhaled asbestos in the respiratory tract could cause an accumulation of environmental carcinogens, thus increasing their local concentration. Moreover, different reports ${ }^{22}{ }^{23}$ have shown that the presence of asbestos in the cellular environment changes benzopyrene transport and its metabolism by the cell and decreases the rate of DNA repair resulting in a larger amount of DNA adducts.

The binding capacity of various mineral fibres for carcinogens thus becomes an important factor in the evaluation of the promotion potential of a particular mineral fibre. We have shown above that chrysotile and attapulgite, a proposed substitute of asbestos, bind a larger proportion of $\mathrm{B}(\alpha) \mathrm{P}, \mathrm{NNN}$, or NAAF than any other mineral fibre tested. This residual carcinogen binding could not be changed significantly after five washing procedures; these binding properties thus represent physicochemical

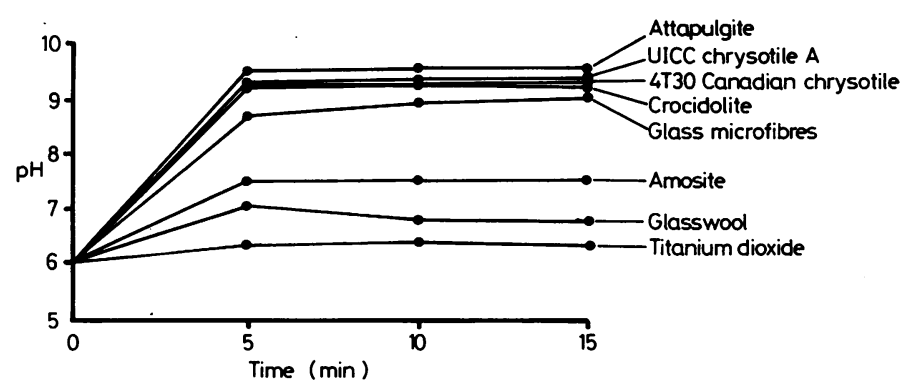

Fig 2 Effect of mineral fibres on water acidity. 
Table 3 V Values for correlation coefficients between the different tests

\begin{tabular}{|c|c|c|c|c|c|c|c|}
\hline & \multicolumn{3}{|c|}{ Binding } & \multirow[t]{2}{*}{ Haemolysis } & \multirow[t]{2}{*}{ Toxicity } & \multirow[t]{2}{*}{$p H$} & \multirow{2}{*}{$\begin{array}{l}\text { Specific surface } \\
\text { area }\end{array}$} \\
\hline & $B(\alpha) P$ & $N N N$ & $N A A F$ & & & & \\
\hline $\begin{array}{l}\text { Binding: } \\
\text { B }(\alpha) \stackrel{P}{\text { NNN }} \\
\text { NAAF } \\
\text { Haemolysis } \\
\text { Toxicity } \\
\text { pH }\end{array}$ & & $<0.05$ & $\begin{array}{l}<0.05 \\
<0.01\end{array}$ & $\begin{array}{l}<0.05 \\
<0.20 \\
<0.05\end{array}$ & $\begin{array}{l}<0.01 \\
<0.05 \\
<0.05 \\
<0.10\end{array}$ & $\begin{array}{l}<0.05 \\
<0.05 \\
<0.01 \\
<0.05 \\
<0.10\end{array}$ & $\begin{array}{l}>0.20 \\
<0.20 \\
<0.01 \\
>0.20 \\
<0.20 \\
>0.20\end{array}$ \\
\hline
\end{tabular}

$\mathrm{B}(\alpha)$ pyrene $=\operatorname{Benzo}(\alpha)$ pyrene.

NNN = Nitrosonornicotine.

NAAF = N-acetyl-2-aminofluorine.

differences in the structure of mineral fibres.

Fournier et al have shown that fibres with basic properties bind polycyclic aromatic hydrocarbons such as $\mathrm{B}(\alpha) \mathrm{P}$ more strongly ${ }^{24}$ : this is the case for attapulgite and chrysotile. NNN and NAAF binding seems to be related to the adsorption properties of the fibres; we have found a positive correlation between the binding of NNN and NAAF and the specific surface of various fibres tested.

To evaluate the toxicity, the promotion effect, or the carcinogenicity of mineral fibres, we have also performed other tests already used to evaluate the in vitro effects of mineral fibres. Chrysotile and attapulgite were found to be more cytotoxic and haemolytic than other mineral fibres tested. We have also evaluated the charge present on the surface of mineral fibres by measuring the change in $\mathrm{pH}$ caused by a constant amount of fibres suspended in deionised water. There was a positive correlation between the apparent basic charge of the fibre and its cellular toxicity.

Various authors ${ }^{25-27}$ and the present data suggest that the toxicity of asbestos is not only size related but that the various physicochemical properties of mineral fibres also play a major part in their toxicity. Recently, the cytotoxic properties of Canadian chrysotile were reduced by chemical treatment. ${ }^{28}$

These various in vitro tests to evaluate the toxicity of mineral fibres as a function of their physicochemical properties should not only produce some explanation for the biological effect of mineral fibres but they should permit a rapid evaluation of the potential toxicity of natural and modified chrysotile or its substitutes.

This work was supported by the Institut de Recherche et de Développement sur l'amiante (IRDA) and by the "Institut de Rechercheur Santé et Sécurité du Travail du Quebec (IRSST) for a studentship to GH.

\section{References}

' Selikoff IJ, Churg J, Hammond EC. Relation between exposure to asbestos and mesothelioma. N Engl J Med 1965; 272:560-5.

${ }^{2}$ McMillan GHG, Pethybridge RJ, Sheers G. Effect of smoking on attack rates of pulmonary and pleural lesions related to exposure to asbestos dust. $\mathrm{Br} J$ Ind Med 1980;37:268-72.

${ }^{3}$ Stanton MF, Wrench S. Mechanism of mesothelioma induction with asbestos and fibrous glass. J Natl Cancer Inst 1972; 48:797-821.

${ }^{4}$ Roy-Chowdhury AK, Money TF, Reeves AL. Trace metals in asbestos carcinogenesis. Arch Environ Health 1973;26:253-5.

${ }^{5}$ Langer AM, Rohl AN, Selikoff IJ, Harlow GE, Prinz M. Asbestos as a co-factor in carcinogenesis among nickel-processing workers. Science 1980;209:420-3.

- Morgan A, Holmes A. Concentration and dimensions of coated and uncoated asbestos fibres in the human lung. $\mathrm{Br} J$ Ind Med 1979;37:27-32.

' Kandaswami C, O' Brien JP. Effects of asbestos on membrane transport and metabolism of benzo $(\alpha)$ pyrene. Biochem Biophys Res Commun 1980;97:794-811.

${ }^{8}$ Chang MJW, Wing W. A probable mechanism for synergistic effect in chrysotile and benzo $(\alpha)$ pyrene induced transformation. In: Proceeding of the 73rd annual meeting. St Louis: American Association for Cancer Research, 1982:51. (Abstract.)

${ }^{9}$ Contour JP, Guerin I, Mouvier G. Adsorption de polluants organiques aminés sur fibres d'amiante. Environ Pollut $1980 ; 1: 243-57$.

${ }^{10}$ Dawe JC, Potter M. Morphologic and biologic progression of a lymphoid neoplasm of the mouse in vivo and in vitro. $\mathrm{Am} \mathrm{J}$ Pathol 1957;33:603.

"Moore GE. Culture of normal human leukocytes. JAMA 1967;199:519.

${ }^{12}$ Speil S, Leineweber JP. Asbestos mineral in modern technology. Environ Res 1969;2:166-208.

${ }^{13}$ Langmuir I. The adsorption of gases on plane surfaces of glass, mica and platinium. Journal of the American Chemical Society 1918;40:1361-1403.

${ }_{14}$ Phillips HJ. Dye exclusion tests for cell viability. In: Kruse PF Jr, Patterson MK Jr, eds. Tissue culure, methods and applications. London: Academic Press, 1973:406-8.

${ }^{15}$ Brunauer S, Emmett PH, Teller E. Adsorption by solid II. In: Weiser HB, ed. A textbook of colloid chemistry. New York: John Wiley and Sons, Inc, 1949:55-67.

${ }^{10}$ Daniel H, Le Bouffant L. Study of quantitative scale for assessing the cytotoxicity of mineral dusts. In: Brown RC, Chamberlain $\mathrm{M}$, Davis R, Gormley IP, eds. The in vitro effects of mineral dusts. London: Academic Press, 1980:33-9.

1 Wright A, Gormley IP, Collings PL, Davis JMG. The cytotoxicities of asbestos and other fibrous dusts. In: Brown RC, Gormley IP, Chamberlain M, Davis R, eds. The in vitro effects of mineral dusts. London: Academic Press, 1980:25-31.

${ }^{18}$ Wade MJ, Lyskin LE, Stanton MF, Frank AL. P388D ${ }_{1}$ in vitro cytotoxicity assay as applied to asbestos and other minerals: its possible relevance to carcinogenicity. In: Brown RC, Gormley 
IP, Chamberlain M, Davis R, eds. The in vitro effects of mineral dusts. London: Academic Press, 1980:352-7.

${ }^{19}$ Miller L, Smith WE, Berliner SW. Tests for effect of asbestos on benzo $(\alpha)$ pyrene carcinogenesis in the respiratory tract. Ann NY Acad Sci 1965;132:489-500.

${ }^{20}$ Shabad LM, Pylev LN, Krivosheera LV, Kulagina TF, Nemenko BA. Experimental studies of asbestos carcinogenicity. J Natl Cancer Inst 1974;52:1175-87.

${ }^{21}$ Mossman BT, Light W, Wei E. Asbestos: mechanisms of toxicity and carcinogenicity in the respiratory tract. Ann Rev Pharmacol Toxicol (in press).

${ }^{22}$ Mossman BT, Eastman A, Landesman JM, Bresnick E. Effects of crocidolite and chrysotile asbestos on cellular uptake and metabolism of $\mathrm{B}(\alpha) \mathrm{P}$ in hamster tracheal epithelial cells. In: Proceeding for the 2nd International Workshop on the in vitro effects of mineral dusts. Arkansas 1982: 11. (Abstract.)

${ }^{23}$ Eastman A, Mossman BT, Bresnick E. Formation and removal of benzo $(\alpha)$ pyrene adducts of DNA in hamster tracheal epithelial cell line. Cancer Res 1981;41:2605-10.
${ }^{24}$ Fournier J, Pezerat H. Etude du mode d'adsorption des $\mathrm{h}$ drocarbures polycycliques aromatiques sur les amiantes. $C_{i}$ du phénenthrène. Journal de Chimie Physique 1982;79:58؟ 96.

${ }^{25}$ Jaurand MC, Bignon J. Systèmes cellulaires in vitro pour évalu le potentiel fibrogénique et cancérogène des particul minérales. Biology of the cell 1982;45:461.

${ }^{26}$ Dunningan J, Nadeau D, Paradis D, et al. Cytotoxic an haemolytic effect of native and chemically modified chrysotil Fourth International Conference on Asbestos IV. B/1 (1981 747-72.

${ }^{27}$ Brody AR, Hill LH. Interaction of chrysotile asbestos with er throcyte membranes. In: Abstracts for the second internation workshop on the in vitro effects of mineral dusts. Arkansa 1982:11.

${ }^{28}$ Cozak D, Barbeau C, Gauvin F. The reaction of chrysotile asbe tos with titanium (III) chloride. Characterization of the rea tion product. Can J Chem 1983;61:2753-60. 